\title{
METAPHOR, CREATIVITY, AND DISCOURSE
}

\section{(Metáfora, criatividade e discurso)}

\author{
Zoltán Kövecses \\ (Eötvös Loránd University, Budapest - HUNGARY)
}

\begin{abstract}
On the "standard" view of conceptual metaphors (Lakoff and Johnson 1980; Kövecses 2002), metaphorical creativity arises from the cognitive processes of extending, elaboration, questioning, and combining conceptual content in the source domain (Lakoff and Turner 1989). I will propose that such cases constitute only a part of metaphorical creativity. An equally important and common set of cases is comprised by what I call "contextinduced" metaphors. I will discuss five types of these: metaphors induced by (1) the immediate linguistic context itself, (2) what we know about the major entities participating in the discourse, (3) the physical setting, (4) the social setting, and (5) the immediate cultural context. Such metaphors have not been systematically investigated so far, though they seem to form a large part of our metaphorical creativity.
\end{abstract}

Key-words: metaphor; creativity; discourse; context.

Resumo: Segundo a visão "padrão" sobre metáforas conceituais (Lakoffe Johnson 1980; Kövecses 2002), a criatividade metafórica surge a partir dos processos cognitivos que envolvem a extensão, a elaboração, o questionamento e da combinação de conteúdo conceitual no dominio fonte (Lakoffe Turner 1989). Proporei aqui que tais casos constituem apenas uma parte da criatividade metafórica. Um conjunto igualmente importante de casos compõe-se do que chamo metáforas "contextualmente induzidas". Discutirei aqui cinco tipos de tais metáforas: aquelas induzidas por (1) o próprio contexto linguístico imediato, (2) aquilo que sabemos a respeito das principais entidades participantes do discurso, (3) o contexto físico, (4) o cenário social, e (5) o contexto cultural imediato. Tais metáforas não têm sido investigadas sistematicamente, embora, pareçam formar uma grande parte da nossa criatividade metafórica.

Palavras-chave: metáfora; criatividade; discurso; contexto.

\section{INTRODUCTION}

One of the criticisms of conceptual metaphor theory (CMT) is that it conceives of metaphors as highly conventional static conceptual structures 
(the correspondences, or mappings, between a source and a target domain). It would follow from this that such conceptual structures manifest themselves in the form of highly conventional metaphorical linguistic expressions (like the metaphorical meanings in a dictionary) based on such mappings. If correct, this view does not easily lend itself to an account of metaphorical creativity. Clearly, we often come across novel metaphorical expressions in real discourse. If all there is to metaphor is static conceptual structures matched by highly conventional linguistic expressions, it would seem that CMT runs into difficulty in accounting for the many unconventional and novel expressions we find in discourse. I will discuss various types of metaphorical creativity in this section.

The paper will examine the interrelations among metaphor, discourse, and metaphorical creativity. I will propose that (1) metaphorical creativity in discourse can involve several distinct cases, (2) conceptualizers rely on a number of contextual factors when they use novel metaphors in discourse.

\section{METAPHORICAL CREATIVITY IN DISCOURSE}

Metaphorical creativity in discourse can involve a variety of distinct forms. In my Metaphor in Culture (2005), I distinguished two types: creativity that is based on the source domain and creativity that is based on the target. "Source-related" creativity can be of two kinds: "sourceinternal" and "source-external" creativity. Source-internal creativity involves cases that Lakoff and Turner (1989) describe as elaboration and extending, where unused source-internal conceptual materials are utilized to comprehend the target. "Source-external" cases of creativity operate with what I called the "range of the target," in which a particular target domain receives new, additional source domains in its conceptualization (Kövecses 2005). The type of creativity in discourse that is based on the target was also described by Kövecses (2005). In it, a particular target that is conventionally associated with a source "connects back" to the source taking further knowledge structures from it. We can call this "targetinduced" creativity.

In the remainder of the paper, I will suggest that there is yet another form of metaphorical creativity in discourse - creativity that is induced by the context in which metaphorical conceptualization takes place. This 
kind of creativity has not been systematically explored in the cognitive linguistic literature on metaphor.

I will term the creativity that is based on the context of metaphorical conceptualization "context-induced" creativity. This occurs where the emergence of a particular metaphorical expression is due to the influence of some aspect of discourse. In particular, five such contextual aspects, or factors, seem to produce unconventional and novel metaphors: (1) the immediate linguistic context itself, (2) what we know about the major entities participating in the discourse, (3) physical setting, (4) social setting, and (5) the immediate cultural context. There are surely others, but I will limit myself to the discussion of these five.

\section{THE EFFECT OF THE LINGUISTIC CONTEXT ON METAPHOR USE}

Let us provisionally think of discourse as being composed of a series of concepts organized in a particular way. The concepts that participate in discourse may give rise to either conventional or unconventional and novel linguistic metaphors. I propose that metaphorical expressions can be selected because of the influence of the immediate linguistic context, that is, the concepts that surround the conceptual slot where we need a word or phrase to express a particular meaning. Jean Aitchison (1987) made an interesting observation that bears on this issue. She noted that in newspaper articles and headlines about (American) football games, the names of the teams may select particular metaphors for defeat and victory. She found such examples as follows in the sports pages of American newspapers: "Cougars drown Beavers," "Cowboys corral Buffaloes," "Air Force torpedoes the Navy," "Clemson cooks Rice" (Aitchison 1987: 143). Metaphors used in these sentences are selected on the basis of the names of football teams. Since beavers live in water, defeat can be metaphorically viewed as drowning; since cowboys corral cattle, the opponent can be corralled; since navy ships can be torpedoed, the opponent can be torpedoed, too; and since rice can be cooked, the same process can be used to describe the defeat of the opponent. The metaphors in the above sentences indicate that the target domain of DEFEAT can be variously expressed as drowning, corralling, etc., the choice depending on the concepts (in this case, corresponding to the names of the teams) that make up the utterances in which the metaphor is embedded. 
Defeating an opponent is a form of symbolic control, in the same way as the sports activities themselves are symbolic activities. In general, defeating an opponent is conceptualized as physically and/or socially controlling an entity (either animate or inanimate). The high-level, schematic conceptual metaphor DEFEAT IS PHYSICAL AND/OR SOCIAL CONTROL is pervasive in English (and also in other languages); metaphorical words for this conceptualization abound: beat, upset, subdue, knock out, clobber, kill, demolish, conquer, crush, dash, destroy, dust, lick, overcome, overwhelm, ruin, stump, vanquish, thrash, trample, trounce, and literally hundreds of others. The words all indicate some form of physical or social control. The words cook and torpedo from Aitchison's examples could be added to this list, although they seem to be somewhat less conventional than the others. Since defeat is conceptualized as physical and social control, it makes sense for the author to use the words cook and torpedo in the conceptual slot in the neighborhood of the concepts RICE and NAVY, respectively. It makes sense because the frame for RICE involves COOKING and the frame for NAVY can involve the weapon TORPEDO, on the one hand, and because COOKING and TORPEDOING are ways of physically controlling an entity, on the other.

There is, however, more complication we need to be aware of. In the SPORTS COMPETITION frame, or more specifically, the AMERICAN FOOTBALL frame, there are two opponents, there is an activity on the basis of which the winner is decided, and a resulting relationship between the two opponents: one opponent defeating the other. Given these minimal elements in the frame, we can say that one team defeats another and we can choose a word from the list above to express this meaning. We do this on the basis of the metaphor DEFEAT IS PHYSICAL/SOCIAL CONTROL. However, how do the concepts of RICE and NAVY that are used in the source domain of this metaphor end up in the AMERICAN FOOTBALl frame? American football teams are not identical to RICE and NAVY; these are concepts that we primarily associate with very different entities, such as plants and the armed forces, respectively. Football teams are not plants and armed forces. Obviously, they enter the frame because they are the names of the two football teams. They enter it on the basis of the metonymy NAME FOR THE INSTITUTION (i.e., NAME OF THE TEAM FOR THE TEAM). This metonymy is crucial in understanding the selection of the particular linguistic expressions for defeat. Without the metonymically introduced names for the teams, it would be much less likely for the author to use the terms cook and torpedo. 
The other two words in the set of examples offered by Aitchison, corral and drown, require similar treatment. We should note, however, that corralling and drowning are even less conventional cases of talking about defeat than cook and torpedo are. What nevertheless makes them perfectly understandable and natural in the context is that the frame for AMERICAN FOOTBALL contains the names Cowboys and Beavers. The words corral and drown are coherent with these names, on the one hand, and they also fit the DEFEAT IS PHYSICAL/SOCIAL CONTROL metaphor, on the other.

In other words, there seem to be three constraints on the use of such metaphorical expressions in discourse. First, the words used must be consistent with an element of a conceptual frame that occurs in the discourse (such as that for DEFEAT). This would simply ensure that we use literal or metaphorical linguistic expressions for DEFEAT, and not for something else. Second, the linguistic metaphor must be consistent with a high-level, schematic metaphor conventionally used for that element, such as DEFEAT). In the case above, it would be DEFEAT IS PHYSICAL/ SOCIAL CONTROL. Third, the linguistic metaphors chosen on the basis of such metaphors should (probably must would be too strong a word here) be consistent with other more specific elements in the same frame (such as AMERICAN FOOTBALL). Such more specific elements within the AMERICAN FOOTBALl frame would be the names of the teams.

\section{The EFFECT OF KNOWLEDGE ABOUT MAJOR ENTITIES IN THE DISCOURSE ON METAPHOR USE}

In other cases, it seems to be our knowledge about the entities participating in the discourse that plays a role in choosing our metaphors in real discourse. Major entities participating in discourse include the speaker (conceptualizer), the hearer (addressee/ conceptualizer), and the entity or process we talk about (topic). I'll discuss two such examples, involving the topic and the speaker/ conceptualizer.

To begin, I will reanalyze an example first discussed in Kövecses (2005). The Hungarian daily Magyar Nemzet (Hungarian Nation) carried an article some years ago about some of the political leaders of neighboring countries who were at the time antagonistic to Hungary. One of them, the then Slovak president, Meciar, used to be a boxer. This gave a Hungarian 
journalist a chance to use the following metaphor that is based on this particular property of the former Slovak president:

A pozsonyi exbokszolóra akkor viszünk be atlanti pontot érö ütést, ha az ilyen helyzetekben megszokott nyugati módra "öklözünk": megvetö távolságot tartva. (Hungarian Nation, September 13, 1997)

We deal a blow worth an Atlantic point to the ex-boxer of Bratislava if we box in a western style as customary in these circumstances: keeping an aloof distance. (my translation, ZK)

Confrontational international politics is commonly conceptualized as war, sports, games, etc. There are many different kinds of war, sports, and games, all of which could potentially be used to talk about confrontational international politics. In all probability, the journalist chose boxing because of his knowledge (shared by many of his readers) about one of the entities that constitute the topic of the discourse.

In using the metaphor CONFRONTATIONAL INTERNATIONAL POLITICS IS BOXING, the author is relying both on some conventional and unconventional mappings. What is common to the war, sports, and games metaphors is, of course, that they all focus on and highlight the notion of winning in relation to the activity to which they apply. This is their shared "meaning focus" (Kövecses 2000, 2002) and this is that makes up the conventional part of the metaphor. The boxer corresponding to the politician and the blows exchanged corresponding to the political statements made are explicitly present in the discourse in question. In addition, we also assume that both boxers want to win and that the participating politicians want the same (whatever winning means in politics). However, the manner in which the boxers box and politicians argue is not a part of the conventional framework of the metaphor. "Keeping an aloof distance" probably comes into the discourse as a result of the author thinking about the target domain of politics. In the author's view, politics regarding Meciar should be conducted in a cool, detached manner. What corresponds to this way of doing politics in boxing is that you box in a way that you keep an aloof distance from your opponent. The process is then similar to what we have seen above in the discussion of the EUROPEAN HOUSE metaphor.

In the previous case, the metaphor was selected and elaborated as a result of what the conceptualizer knows about the topic. It is also possible 
to find cases where the selection of a metaphor depends on knowledge that the conceptualizer has about himself or herself. What is especially intriguing about such cases is that the author's (conceptualizer's) knowledge about him- or herself does not need to be conscious. The next example, taken from my previous work (Kövecses 2005) but reanalyzed here, demonstrates this possibility. As one would expect, one important source of such cases is the area of therapy or psychological counseling. In a therapeutic context people commonly create novel metaphors as a result of unique and traumatic life experiences. The metaphors that are created under these circumstances need not be consciously formed. The example comes from an article in the magazine $A \in E($ March, 2003) about photographic artist Frank Jump.

Frank Jump photographs old painted mural advertisements in New York City. He has AIDS, but he has outlived his expected life span. His life and his art are intimately connected metaphorically. The conceptual metaphor operative here could be put as follows: SURVIVING AIDS DESPITE PREDICTIONS TO THE CONTRARY IS FOR THE OLD MURAL ADVERTISEMENTS TO SURVIVE THEIR EXPECTED “LIFE SPAN." At first, Jump was not consciously aware that he works within the frame of a conceptual metaphor that relies on his condition. In his own words:

In the beginning, I didn't make the connection between the subject matter and my own sero-positivity. I was asked to be part of the Day Without Art exhibition a few years ago and didn't think I was worthy—other artists' work was much more HIVspecific. ... But my mentor said, "Don't you see the connection? You're documenting something that was never intended to live this long. You never intended to live this long." [p. 27; italics in the original]

The mentor made the conceptual metaphor conscious for the artist. I believe something similar is happening in many cases of psychotherapy and counseling.

It is clear that the metaphor SURVIVING AIDS DESPITE PREDICTIONS TO THE CONTRARY IS FOR THE OLD MURAL ADVERTISEMENTS TO SURVIVE THEIR EXPECTED "LIFE SPAN" is anything but a conventional conceptual metaphor. The metaphor is created by Frank Jump as a novel analogy - the unconscious but nevertheless real analogy between surviving one's expected life span as a person who has AIDS and the survival of the mural advertisements that were created to be around on the walls of buildings in New York City for only a limited amount of time. In this case, (unconscious) self-knowledge 
leads the conceptualizer to find the appropriate analogy. The analogy is appropriate because the source and the target domains share schematic structural resemblance; namely, an entity existing longer than expected. The resulting metaphor(ical analogy) is novel and creative and it comes about as a result of what the conceptualizer knows about himself.

\section{THE EFFECT OF PHYSICAL SETTING ON METAPHOR USE}

The physical setting may also influence the selection and use of particular metaphors in discourse. The physical setting comprises, among possibly other things, the physical events and their consequences that make up or are part of the setting, the various aspects of the physical environment, and the perceptual qualities that characterize the setting. I'll briefly discuss an example for each.

The first of these, physical events and their consequences, is well demonstrated by a statement made by an American journalist who traveled to New Orleans to do an interview with Fats Domino, the famous American musician and singer, two years after the devastation wreaked by hurricane Katrina, when the city of New Orleans was still struggling with many of the consequences of the hurricane. The journalist comments:

The 2005 hurricane capsized Domino's life, though he's loath to confess any inconvenience or misery outside of missing his social circle ... (USA TODAY, 2007, September 21, Section 6B)

The metaphorical statement "The 2005 hurricane capsized Domino's life" is based on the general metaphor LIFE IS A JOURNEY and its more specific version LIFE IS A SEA JOURNEY. The SEA JOURNEY source domain is chosen probably because of the role of the sea in the hurricane. More importantly, it should be noted that the verb capsize is used (as opposed to, say, run aground), though it is not a conventional linguistic manifestation of either the general JOURNEY or the more specific SEA JOURNEY source domains. I suggest that this verb is selected by the journalist as a result of the (still) visible consequences in New Orleans of the hurricane as a devastating physical event. The physical setting thus possibly triggers extension of an existing conventional conceptual metaphor and causes the speaker/ conceptualizer to choose a metaphorical expression that best fits that setting. 
Next, let us consider environmental conditions as a part of the physical setting. The physical setting as a potential cause of, or factor in, which metaphors we choose was first studied by Boers (1999). He started out from the following general hypothesis. People will make more extensive use of a source domain when that particular source domain becomes more salient for them under certain circumstances. In other words, certain changes in the circumstances of the communicative situation may make people more aware of a particular source domain, and this may result in an increased use of the source domain in metaphorical conceptualization. The specific hypothesis was that the source domain of HEALTH will be especially productive of linguistic expressions in the winter because this is the time when, at least in countries of the northern hemisphere, people are more aware of their bodies through the more frequent occurrence of illnesses (such as colds, influenza, pneumonia, bronchitis). The particular target domain that was selected for the study was ECONOMY. Thus, according to the hypothesis, we can expect an increase in the relative salience of the ECONOMY IS HEALTH metaphor in the winter period. The salience of the HEALTH domain was assessed in terms of the frequency of health-related metaphorical expressions for economy.

In order to test the hypothesis, Boers counted all the metaphorical expressions that have to do with economy and that are based on the HEALTH source domain in the editorials of all issues of the English weekly magazine The Economist over a period of ten years. The study resulted in a sample of over one million words. Here is a selection of some of the metaphorical expressions that he identified: "bealthy companies," "sickly firms," "economic remedy," "symptoms of a corporate disease," "a financial injection," "artbritic markets," "economic recovery," and many others. The heavy presence of such and similar expressions shows that economy is commonly talked and thought about in terms of bodily health. The question for the researcher was whether there was any fluctuation in the frequency of use of the HEALTH metaphor from season to season. Boers found that the frequency of the metaphor was highest between the months of December and March. The same result was found systematically for the ten years under investigation. During this period, the frequency of health-related metaphors for economy went up and stayed higher in the winter. This finding supported the hypothesis. When the HEALTH domain becomes more salient for people, they make more extensive use of it than when it is less salient. 
We can reinterpret Boers' findings in the following way. Since the physical setting is part of the communicative situation, it may play a role in selecting particular metaphorical source domains. In the present example, wintertime is more likely to lead to the selection of health-related metaphors than to other metaphors, simply because such metaphors may be higher up in awareness than others due to the adverse impact of the physical environment on conceptualizers.

\section{THE EFFECT OF SOCIAL SETTING ON METAPHOR USE}

When we use metaphors, we use them in a social context as well. The social context can be extremely variable. It can involve anything from the social relationships that obtain between the participants of the discourse through the gender roles of the participants to the various social occasions in which the discourse takes place. Let us take an example for the last possibility from the American newspaper USA TODAY.

As mentioned above, in 2007 the newspaper carried an article about Fats Domino, one of the great living musicians based in flood-stricken New Orleans. In the article, the journalist describes in part Domino's life after Katrina - the hurricane that destroyed his house and caused a lot of damage to his life and that of many other people in New Orleans. The subtitle of the article reads:

The rock ' $n$ ' roll pioneer rebuilds his life—and on the new album 'Goin' Home,' his timeless music. (USA TODAY 2007, September 21, Section 6B)

How can we account for the use of the metaphor "rebuilds his life" in this text? We could simply suggest that this is an instance of the LIFE Is A BUILDING conceptual metaphor and that whatever meaning is intended to be conveyed by the expression is most conventionally conveyed by this particular conceptual metaphor and this particular metaphorical expression. But then this may not entirely justify the use of the expression. There are potentially other conceptual metaphors (and corresponding metaphorical expressions) that could also be used to achieve a comparable semantic effect. Two that readily come to mind include the LIFE IS A JOURNEY and the LIFE IS A MACHINE conceptual metaphors. We could also say that $\mathrm{x}$ set out again on his/her path or that after his/her life broke down, $\mathrm{x}$ got it to 
work again or restarted it. These and similar metaphors would enable the speaker/ conceptualizer and the hearer to come to the interpretation that the rebuilding idea activates.

However, of the potentially possible choices it is the LIFE IS A BUILDING metaphor is selected for the purpose. In all probability this is because, at the time of the interview, Domino was also in the process of rebuilding his house that was destroyed by the hurricane in 2005. If this is correct, it can be suggested that the social situation (rebuilding his house) triggered, or facilitated, the choice of the conceptual metaphor LIFE IS A BUILDING. In other words, a real-world instance of a source domain is more likely to lead to the choice of a source concept of which it is an instance than to that of a source domain of which it is not. In this sense, the social setting may play a role in the selection of certain preferred conceptual metaphors, and hence of certain preferred metaphorical expressions in discourse.

In such cases, the emerging general picture seems to be as follows: There is a particular social setting and there is a particular meaning that needs to be activated. If the meaning can be activated by means of a metaphorical mapping that fits the social setting, speakers/ conceptualizers will prefer to choose that mapping (together with the linguistic expression that is based on the mapping). More simply, if the social setting involves an element that is an instance of an appropriate source domain, speakers are likely to use that source domain.

\section{THE EFFECT OF THE IMMEDIATE CULTURAL CONTEXT ON METAPHOR USE}

The social setting can be relatively easily distinguished from the cultural context when we have to deal with social roles, social relations, and social power. However, the social setting is less clearly distinguishable from what I call the "cultural context" in many other cases. The situation I wish to describe in this section is probably more cultural than social, in that it lacks such straightforward social elements and characteristics as power, relations, and roles.

Consider the following example taken from the San Francisco Chronicle, in which Bill Whalen, a professor of political science in Stanford and an advisor to Arnold Schwarzenegger, uses metaphorical language concerning the actor who later became the governor of California: 


\begin{abstract}
"Arnold Schwarzenegger is not the second Jesse Ventura or the second Ronald Reagan, but the first Arnold Schwarzenegger," said Bill Whalen, a Hoover Institution scholar who worked with Schwarzenegger on his successful ballot initiative last year and supports the actor's campaign for governor.

"He's a unique commodity - unless there happens to be a whole sea of immigrant body builders who are coming here to run for office. This is 'Rise of the Machine,' not 'Attack of the Clones."' (San Francisco Chronicle, A16, August 17, 2003)
\end{abstract}

Of interest in this connection are the metaphors He's a unique commodity and particularly This is 'Rise of the Machine,' not 'Attack of the Clones.' The first one is based on a completely conventional conceptual metaphor: PEOPLE ARE COMMODITIES, as shown by the very word commodity to describe the actor. The other two are highly unconventional and novel. What makes Bill Whalen produce these unconventional metaphors and what allows us to understand them? There are, I suggest, two reasons. First, and more obviously, it is because Arnold Schwarzenegger played in the first of these movies. In other words, what sanctions the use of these metaphorical expressions has to do with the knowledge that the conceptualizer (Whalen) has about the topic of the discourse (Schwarzenegger), as discussed in a previous section. Second, and less obviously but more importantly, he uses the metaphors because these are movies that, at the time of speaking (i.e., 2003), everyone knew about in California and the US. In other words, they were part and parcel of the immediate cultural context. Significantly, the second movie, Attack of the Clones does not feature Schwarzenegger, but it is the key to understanding of the contrast between individual and copy that Whalen is referring to.

Given this knowledge, people can figure out what Whalen intended to say, which was that Schwarzenegger is a unique individual and not one of a series of look-alikes. But figuring this out may not be as easy and straightforward as it seems. After all, the metaphor Rise of the Machine does not clearly and explicitly convey the idea that Schwarzenegger is unique in any sense. (As a matter of fact, the mention of machines goes against our intuitions of uniqueness.) However, we get this meaning via two textual props in the text. The first one is a series of statements by Whalen: "Arnold Schwarzenegger is not the second Jesse Ventura or the second Ronald Reagan, but the first Arnold Schwarzenegger" and "He's a unique commodity - unless there happens to be a whole sea of immigrant body builders who are coming here to run for office." What seems to be 
the case here is that the speaker emphasizes the idea of individuality before he uses the MACHINE metaphor. But not even this prior emphasis would be sufficient by itself. Imagine that the text stops with the words "...This is 'Rise of the Machine." I think most native speakers would be baffled and have a hard time understanding what Whalen intended to say in this last sentence. Therefore, in order to fully understand the discourse we badly need the second textual prop, which is: "not 'Attack of the Clones." It is against the background of this phrase that we understand what the metaphorical expression Rise of the Machine might possibly mean.

In other words, in this case we have an entirely novel (but contextually motivated) metaphor in the discourse. In order to understand the meaning of this metaphorical phrase we need support from the neighboring linguistic context. In the present example, it is provided in the form of the two contextual props discussed above.

\section{THE COMBINED EFFECT OF FACTORS ON METAPHOR USE}

For the sake of the clarity of analysis, I have tried to show the relevance to the selection of discourse metaphors of each of the factors one by one. But this does not mean that in reality they always occur in an isolated fashion. As a matter of fact, it is reasonable to expect them to co-occur in real discourse. For example, a person's concerns, or interests, as a factor may combine with additional knowledge about himself or herself, as well as the topic of the discourse, and the three can, in this way, powerfully influence how the conceptualizer will express himself or herself metaphorically. The next and final example demonstrates this possibility in a fairly clear way.

At the time of working on the present article (January through March, 2008), there was heated debate in Hungarian society about whether the country should adopt a health insurance system, similar to that in the U.S.A., based on competing privately-owned health insurance companies, rather than staying with a single, state-owned and state-regulated system. As part of the debate, many people volunteered their opinion on this issue in a variety of media, the Internet being one of them. As I was following the debate on the Internet, I found an article that can serve, in my view, as a good demonstration of a situation in which one's use of metaphors in a discourse is informed by a combination of factors, not just a single one. 
A Hungarian doctor published a substantial essay in one of the Hungarian news networks about the many potential undesirable consequences of the proposed new privatized system. He outlines and introduces what he has to say in his essay in the following way (given first in the Hungarian original):

Dolgozatom a gondolkodási idöben született.

Célkitüzése a törvény várható hatásainak elemzése.

Módszereiben az orvosi gondolkodást követi.

A magyar egészségügyet képzeli a beteg helyzetébe.

Kezelöorvosnak a kormányt tekinti, és konzulensként a szakértö ket illetve a szerzöt magát kéri fel.

A prognózis meghatározás feltételének tekinti a helyes diagnózist.

Végül röviden megvizsgálja van-e alternatív kezelési lehetöség.

Here's an almost literal translation of the text into English (I have used quotation marks for cases where there is no clear equivalent for a Hungarian word or expression in English or I am not aware of one):

This paper was born in the period when people think about the issue.

Its objective is to analyze the expected effects of the law.

In its methods, it follows the way doctors think.

It imagines Hungarian healthcare as the patient.

It takes the government as the attending physician, and invites experts and the author (of the article) himself to be the consultants.

It considers the correct diagnosis to be the precondition for predicting the prognosis.

Finally it briefly examines if there is an alternative possibility for treatment.

Unless the author of the article deliberately wishes to provide an illustration for the use of metaphors in discourse and/or has read Lakoff and Johnson's Metaphors We Live By, and/or, even less likely, that s/he has read my Metaphor in Culture (and I doubt that either of these is the case), this is a remarkable example of how a combination of contextual factors can influence the way we often speak/write and think metaphorically. The author of the article is a doctor himself/herself, we can assume s/he has a great deal of interest in his/her job (s/he took the trouble of writing the article), and s/he is writing about Hungarian healthcare. The first of these is concerned with what I called knowledge about the speaker/conceptualizer; the second corresponds to personal concern, or interest (related to the 
speaker); and the third involves what was called the topic of the discourse. It seems that the three factors are jointly responsible for the way the author uses metaphors in the discourse (and, given this example, for how s/he, in addition, actually structures what $\mathrm{s} /$ he says). Needless to say, many other combinations of factors can be imagined and expected to co-occur in and influence real discourse.

\section{AN EXTENDED VIEW OF METAPHORICAL CREATIVITY}

We are now in a position to discuss two important issues regarding metaphorical creativity. First, we can ask what the sources of metaphorical creativity are, and second, we can try to tackle the issue of the role of the communicative situation in metaphorical creativity.

What are the sources of metaphorical creativity?

The "standard" version of CMT operates with largely uncontextualized or minimally contextualized linguistic examples of hypothesized conceptual metaphors. The conceptual metaphors are seen as constituted by sets of mappings between the source and the target domains. The mappings are assumed to be fairly static conceptual structures. The linguistic metaphors that are motivated by such static correspondences are entrenched, conventional expressions that eventually find their way to good, detailed dictionaries of languages. Dictionaries and the meanings they contain represent what is static and highly conventional about particular languages. In this view it is problematic to account for metaphorical creativity. How does this somewhat simplified and rough characterization of "standard" CMT change in light of the work reported in this paper?

If we look at metaphors from a discourse perspective and if we try to draw conclusions on the basis of what we have found here, we can see three important sources of metaphorical creativity. The first is the type of creativity that arises from the source domain (in its source-internal and source-external versions), the second derives from the target domain, and the third emerges from the context. Since I have discussed the first two elsewhere (see Kovecses, 2005), I'll deal with the third type only.

The third type of metaphorical creativity is what I called "contextinduced" creativity. To the best of my knowledge, apart from some sporadic 
instances (such as Aitchison 1987; Koller 2004; Kövecses 2005; Semino, in press/ 2008; Benczes, to appear), the issue of context-induced metaphorical creativity has not been systematically investigated. A considerable portion of novel metaphorical language seems to derive from such contextual factors as the immediate linguistic context, knowledge about discourse participants, physical setting, and the like. It remains to be seen how robust the phenomenon is and whether it deserves serious further investigation. Based on an informal collection of data from a variety of newspapers, it appears that the context provides a major source of motivation for the use of many novel metaphors. These metaphors are clearly not, in Grady's (1999) classification, either resemblance or correlation-based cases. They seem to have a unique status, in that they are grounded in the context in which metaphorical conceptualization is taking place.

\section{THE ROLE OF CONTEXT IN METAPHORICAL CREATIVITY}

Many of the examples of unconventional metaphoric language we have seen in this paper could simply not be explained without taking into account a series of contextual factors. Five such factors have been identified, but possibly there are more. My claim is that in addition to the well studied conceptual metaphors and metaphorical analogies used to convey meanings and achieve rhetorical functions in discourse, conceptualizers are also very much aware and take advantage of the various factors that make up the immediate context in which metaphorical conceptualization takes place.

The linguistic context is constituted by the various conceptual frames (including temporary mental spaces) and symbolic units (form-meaning pairs, or, simply, words) representing and activating the frames. Metaphoricallyused expressions (i.e., metaphoric symbolic units) are placed into this flow of frames and words at appropriate points in the manner explained in the discussion of several of the examples. Thus the most immediate context in which metaphorical expressions are used is the linguistic context; more specifically and precisely, the frames that immediately precede and provide the slot into which linguistic metaphors can be inserted. This flow of discourse can be imagined as a line of successive (though not necessarily temporally arranged) frames (with the frames commonly nested in more general frames). 
The major entities that participate in the discourse are the speaker/ conceptualizer, the topic, and the hearer/ conceptualizer. The speaker and the hearer are both also conceptualizers in the sense that both the production and understanding of discourse requires the activation of literal, metonymic, and metaphoric frames. More importantly for the present purpose, the speaker may have, sometimes detailed, knowledge about him- or herself, the hearer, and the topic. As we have seen, in the case of the speaker this knowledge need not be conscious. The knowledge the speaker has about these entities may form the basis of the use of both conventional and unconventional metaphors in discourse.

Discourses do not occur in a vacuum. The three types of situations that I have considered in the paper include the physical environment, the social setting, and the immediate cultural context. This means that the speaker and the hearer are communicating about a topic (i.e., producing and reproducing a discourse) in a specific and immediate physical, social, and cultural context. The use of metaphors is affected by less specific and less immediate contexts as well, such as the "broader cultural context" (see Kövecses, 2005), but this larger context was not the focus of this paper. Moreover, as was noted above, each of these contextual factors comes in a variety of distinct forms, and they can shade into each other. Finally, all the factors can affect the use of metaphors in discourse simultaneously, and they can do so in various combinations.

We can imagine the three factors as frames that are nested in one another, such that the physical setting as the outermost frame includes the social frame that includes the cultural frame, where we find the speaker/ conceptualizer, the hearer/ conceptualizer, and the topic, as well as the diagram for the flow of discourse. These contextual factors can trigger, singly or in combination, the use of conventional or unconventional and novel metaphorical expressions in the discourse. We can represent the joint workings of these factors in the diagram below.

As noted, all the factors can trigger the use of metaphors in discourse. In some cases, the contextual factors will simply lead to the emergence and use of well-worn, conventional metaphorical expressions, but in others they may produce genuinely novel expressions. We can call this mechanism the "pressure of coherence," a notion I introduced elsewhere (Kövecses 2005). The pressure of coherence includes all the mechanisms that lead to 
the use of particular metaphors in discourse. The core idea is that we try to be coherent, in addition to the body, with most of the other, especially contextual, factors that regulate what we say and think.

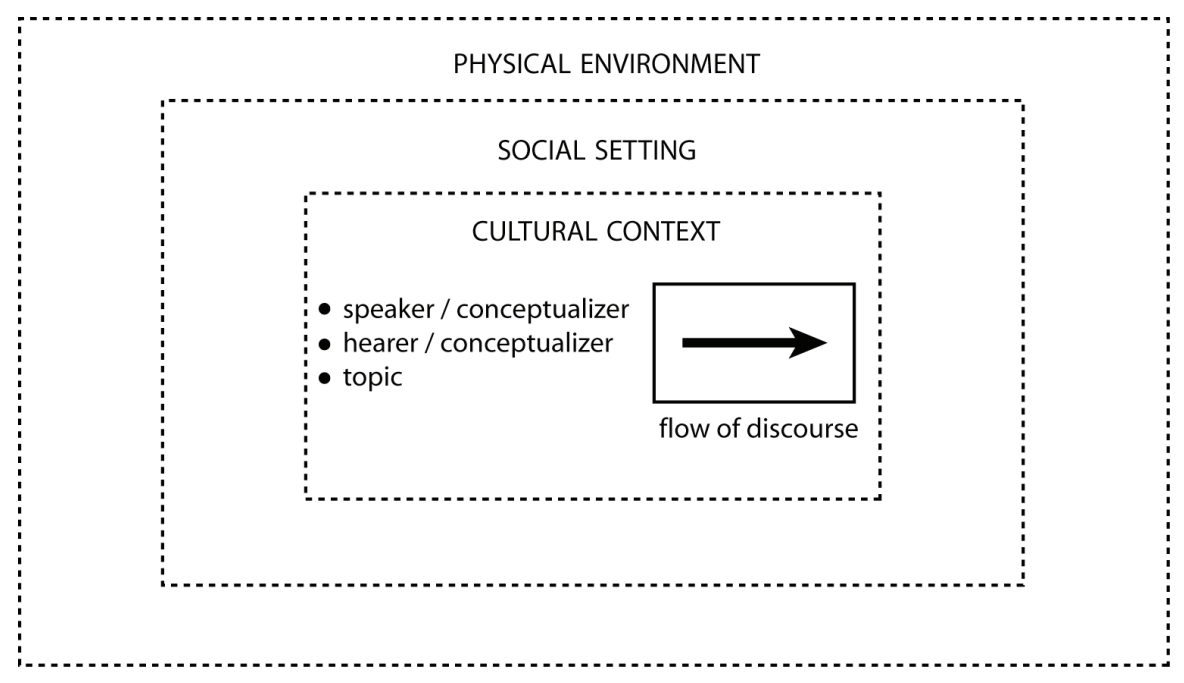

\section{CONClusions}

The paper has examined the interrelations among the notions of metaphor, discourse, and creativity. Several important connections have been found.

First, metaphorical creativity in discourse can involve several distinct cases: (a) the case where a novel source domain is applied or novel elements of the source are applied to a given target domain (source-induced creativity); (b) the case where elements of the target originally not involved in a set of constitutive mappings are utilized and found matching counterparts in the source (target-induced creativity); (c) the case where various contextual factors lead to novel metaphors (context-induced creativity).

Second, context plays a crucial role in understanding why we use certain metaphors as we produce discourse. Conceptualizers seem to rely on a number of contextual factors when they use metaphors in discourse. The ones that have been identified in the paper include the immediate linguistic context, the knowledge conceptualizers have about themselves and the topic, the immediate cultural context, the social context, and the 
physical setting. Since all of these are shared between the speaker and hearer (the conceptualizers), the contextual factors facilitate the development and mutual understanding of the discourse.

Given the evidence in the paper, we can conclude that conceptualizers try and tend to be coherent not only with their bodies (as is the case with correlational metaphors) but also with the various facets of the context in the course of metaphorically conceptualizing the world.

Recebido em junho de 2009

Aprovado em janeiro de 2010

E-mail: zkovecses@ludens.elte.hu

\section{REFERENCES}

Aitchison, Jean. 1987. Words in the Mind. Oxford: Blackwell.

BenCzes, Réka. Setting limits on creativity in the production and use of metaphorical and metonymical compounds. In: Sascha Michel and Alexander Onysko (eds.). Cognitive Approaches to Word Formation. Berlin and New York: Mouton de Gruyter. (In Press)

Boers, Frank. 1999. When a bodily source domain becomes prominent. In R. Gibbs and G. Steen (Eds.) Metaphor in Cognitive Linguistics, 47-56. Amsterdam: John Benjamins.

GrADY, Joseph. 1999. A typology of motivation for conceptual metaphors. Correlations vs. resemblance. In Ray W. GibBs and Gerard J. STEEN (Eds.) Metaphor in Cognitive Linguistics. Amsterdam and Philadelphia: John Benjamins, 79-100.

Koller, Veronika. 2004/2008. Metaphor and Gender in Business Media Discourse: a Critical Cognitive Study. Basingstoke and New York: Palgrave.

Kövecses, Zoltán. 2000. The scope of metaphor. In A. BArcelona (Ed.) Metaphor and Metonymy at the Crossroads. Berlin: Gruyter, 79-92. 2002. Metaphor. A Practical Introduction. New York: Oxford University Press. 2005. Metaphor in Culture. Universality and Variation. New York: Cambridge University Press.

Lakoff, George and Mark Johnson. 1980. Metaphors We Live By. Chicago: University of Chicago Press. 
Lakoff, George and Mark Turner. 1989. More Than Cool Reason. A Field Guide to Poetic Metaphor. Chicago: University of Chicago Press.

Semino, Elena. 2008. Metaphor in Discourse. Cambridge: Cambridge University Press. 